\title{
Eva Canel, una mujer de paradojas
}

\author{
María del Carmen Barcia Zequeira \\ Universidad de La Habana
}

Eva Canel fue una mujer de entre siglos, vivió en los años en que los presupuestos de la modernidad alcanzaban a las capas populares. Su vida estuvo signada por paradójicas posiciones: conservadora en la vida real, tanto por sus perspectivas políticas como por sus criterios con respecto al papel de la mujer en la sociedad, abordó en sus novelas y obras de teatro complejos problemas sociales a los cuales dio las soluciones más audaces. Fue directora del periódico La Cotorra, en La Habana, y de la revista Cosmos, en Buenos Aires. Aunque algunos la han considerado como una escritora americana por su larga estancia en el continente, ella se valoraba como una representante del españolismo más intransigente.

Este artículo aborda algunas de las contradicciones presentes en una mujer con aspiraciones en la vida intelectual y responsabilidades familiares, entre los años finales del siglo XIX y los primeros del XX.

En los años noventa del siglo XIX la sociedad cubana, en pleno cambio social, afrontaba una situación políticamente compleja. Cuatro años antes había cesado totalmente la esclavitud y desde que su liquidación se hizo evidente se fue incrementando la inmigración de fuerza de trabajo blanca, procedente de la Península. Aunque la mayor parte de los recién llegados no aspiraban a consumir su existencia en los cañaverales sino a disputar a los negros y mestizos los trabajos urbanos - labores artesanales y de servicios-, que desde tiempos inmemoriales estos realizaban, muchos constituyeron una emigración de tipo golondrina, que buscaba con el ahorro de sus jornales, mejorar su situación y la de las familias que habían dejado atrás a su regreso a sus aldeas y comarcas.

En las capas populares se manifestaba el acelerado proceso de cambios, las mujeres blancas, negras o mestizas reclamaban, los inmigrantes establecían redes de solidaridad, se abrían nuevos espacios y se transformaban otros, todo anunciaba una nueva época.

Pero paralelamente a la movilidad que ese proceso entrañaba, tanto para las capas urbanas como para las rurales de la sociedad cubana, la situación política se estaba tornando nuevamente peligrosa para la administración colonial. Los problemas económicos que habían llevado a Cuba a la Guerra de los Diez Años permanecían sin resolver, razón por la cual la situación era comprometida, las elites económicas procuraban constituir un grupo de presión que, supuestamente por encima de todo interés político, 
fuese capaz de obtener del gobierno colonial algunas de las reformas que necesitaban para el desarrollo de sus intereses económicos. ${ }^{1}$ En ese especial contexto llegaba a la Isla de Cuba Eva Canel, o Eva Agar Infanzón Canel, que era su nombre completo.

Las circunstancias que la trajeron a la Isla se derivaban del fallecimiento en 1889 de su marido, Pedro Perillán Buxó, que se había establecido en la Isla cinco años antes. ${ }^{2}$

\section{Eva mujer: esposa, madre y abuela}

Había nacido en 1857 en el poblado asturiano de Ocaña, huérfana desde los tres años fue llevada a Madrid por su madre cuyo apellido siempre usó. ¿Reconocimiento expreso hacia una persona que jamás menciona en sus cartas o escritos?, ¿desconocimiento del padre que no podía recordar?, ¿búsqueda de un apellido más sonoro para sus afanes de escritora? Al parecer tampoco sabía mucho de su familia materna pues fue en su retorno a Cuba en 1914, cuando tuvo noticias concretas sobre su abuelo. ${ }^{3}$ Tal vez lo de cambiarse el patronímico fuese una costumbre familiar pues Pedro Díaz-Canel Lastra y Acevedo, se hizo llamar Pedro Canel Acevedo, fue abogado, poeta y arqueólogo, y como tal, miembro de la Academia de Historia.

A los trece años Eva quiso ser actriz de teatro, en esas gestiones conoció al catalán Pedro Perillán Buxó, nueve años mayor que ella, con quien se casó siendo apenas una adolescente de catorce años. De esta unión nació su único hijo, Eloy. El matrimonio sólo duró catorce años, desde los 27 vivía sola y a los treinta y dos era viuda; jamás volvió a casarse. Sus referencias al marido son escasas y contradictorias, tuvieron una vida inestable y llena de aventuras. Pedro tuvo que abandonar la Península por razones políticas cuando aún estaban recién casados, vivieron en Montevideo (Uruguay), Buenos Aires (Argentina), Santiago y Valparaíso (Chile), y se

1 Para más elementos sobre esta situación puede consultarse el libro de María del Carmen Barcia: Elites y grupos de presión en Cuba. 1868-1898, La Habana, 1998.

2 En sus escritos Eva expresa que ella estaba en Barcelona, disponiéndose a embarcar para Cuba, cuando murió su marido, que del equipaje de éste le mandaron muy poco: "Su magnífica colección de bastones pasó a mejores manos, ídem sus diccionarios y su escopeta de caza, lo mismo ocurrió con sus trabajos inéditos”. Canel, Eva: Lo que vi en Cuba (a través de la Isla), La Habana, 1916, pág. 10.

3 Tuvo noticias de su abuelo durante una estancia en Puerto Padre al leer una obra de Bernardo Acevedo titulada Boal y su consejo. 
establecieron en estancias más largas, en Bolivia y Perú. Sus vidas en tierras americanas rayaron la aventura, cuestión que debió marcarla profundamente. Regresaron a la Península en 1881, cuatro años más tarde, salía Perillán Buxó en un viaje a Cuba del que no cual no regresó. Pedro no le dejó bien alguno por lo cual tuvo que vivir en Barcelona al amparo de su tío político, Saturnino Lacal y Ramón. ${ }^{4}$

De su marido expresaba que "tenía un nombre en la literatura y en el periodismo y la prensa latina en general", ${ }^{5}$ pero todo parece indicar que era su antítesis política, pues defendía a los autonomistas, en la prensa española, sobre todo a los puertorriqueños. ${ }^{6}$

Pero sus discrepancias también se manifestaron en otros planos, ya una anciana escribía al marqués de Navas: "mi marido, que no ha economizado producirme disgustos, jamás hubiera consentido que nadie me los diese". ¿Esas desavenencias eran sólo profesionales? No lo sabemos, pero al menos éstas resultaban evidentes pues con franqueza expresaba que si Perillán no hubiese muerto, ella "habría venido a Cuba a ser lo que había sido antes; una esposa sumisa que escribía de vez en cuando sin consultarle nada y por lo cual, algunas veces, le ocasionaba disgustillos sin mayor importancia, que le hacían mucha gracia y los eludía". ${ }^{8}$ No obstante, la Canel expresa que en vida de su marido había publicado mucho sobre América en La Ilustración Artística de Barcelona, en El Ferrocarril de Montevideo, en La Estrella de Panamá y en El Pueblo de Ponce.9

A pesar de esa autosuficiencia, fiel reflejo de su fuerte personalidad, cuando ya viuda vino a Cuba y comenzó a publicar novelas, fue impugnada por algunos que dudaban de su autoría. Saturnino Martínez, ${ }^{10}$ por ejemplo, consideraba que éstas eran de Romero Rubio, en tanto otros las atribuían a parte de la obra inédita de su marido. La calumnia no concluyó hasta que se estrenó El Indiano. Ante esta situación Eva reaccionó como

4 Canel: Lo que vi en Cuba..., pág. 11.

5 Canel, Eva: El divorcio ante la familia y la sociedad, Buenos Aires, 1903, pág. 30.

6 Entre sus obras, algunas publicadas después de su muerte, se encuentran Pelos y señales, Retratos de cuerpo entero (bocetos político sociales) (1871), El sitio de París (1871), Una crisis conyugal (1872), El ideal de la niña (1872), Apolo y Apeles (1873), La Copa de Plata (1873), José Olaya (1878), Los matadores (1884), Bengalas (1887), Las llaves de San Pedro, Las Macetas, El maldito o Un río de oro (1887).

7 Biblioteca del Palacio Real de Madrid (BPR, en adelante), "Carta de Eva Canel al marqués de Navas, 8 de julio de 1929".

8 Canel: Lo que vi en Cuba..., pág. 10.

9 Ibídem.

10 Destacado dirigente obrero de tendencia reformista, publicó La Razón y La Aurora. 
solía hacerlo "cuanto más decían que los escritos no eran míos mas pruebas daba de que no había ningún hombre que me superase en valentía moral"." ${ }^{11}$

De una u otra forma resulta evidente que la Canel logró su realización profesional a partir de la muerte de su marido y que tal vez el temor a perder la independencia profesional que había obtenido influyera en su decisión de no contraer matrimonio nuevamente.

Independientemente de la agitada vida profesional que comenzó a desarrollar a partir de 1891, fue una madre preocupada primero y una abuela protectora después. Todo parece indicar que el viaje a Cuba en marzo de ese año estuvo relacionado con la educación de Eloy, éste, influenciado por la dama de compañía de su madrina, una francesa que había vivido por más de treinta años en los Estados Unidos, quería estudiar en una escuela norteamericana, Eva lo matriculó en la Military School de Yonkers. Pero estas acciones tuvo que realizarlas desde La Habana, no por comodidad sino por necesidad, el viaje que se le facilitó fue en un vapor de la Trasatlántica Española, con el pasaje gratuito que le obsequió la marquesa de Comillas, ${ }^{12}$ tenía además los contactos dejados por Pedro y las cartas de recomendación que le había facilitado Antonio Cánovas del Castillo para algunas personalidades de la administración colonial.

A pesar de las largas separaciones que debieron soportar, entre Eva y su hijo existió siempre una relación estrecha y mutuamente protectora, que evidenció en los momentos difíciles. En 1898 Eloy estudiaba en la Universidad de Barcelona, cuando los Estados Unidos declararon la guerra a España decidió incorporarse al Regimiento de Artillería de Voluntarios. Al parecer tenía un carácter tan decidido como su madre; consiguió el pasaporte, desde Santander llegó a Saint Thomas, en un pequeño barco de cabotaje - el Olinda Rodríguez, que rompió el bloqueo, y entró en San Juan de Puerto Rico-, desde allí, tras ser apresado por un crucero norteamericano, logró llegar a Port au Prince donde el cónsul español le enroló en la expedición de la goleta María Amelia para llevar víveres al hospital de Baracoa. Se quedó al mando del fuerte de esa villa y para no rendirse, salió en una embarcación y fue recogido en el Canal de Maternillos por el Infanta Isabel. ${ }^{13}$

11 Canel: Lo que vi en Cuba..., pág. 15.

12 Ibídem, págs. 12-13.

13 Su compañero en esa aventura fue Arturo Díaz. Ibídem, págs. 365-367. 
Años más tarde, en 1908, cuando Eva sufrió un colapso nervioso, probablemente por el trabajo excesivo al frente de la revista Kosmos, del semanario Vida Española y de su imprenta, Eloy viajó a Buenos Aires, liquidó la pequeña empresa y la hizo descansar.

Una situación similar se manifiesta desde 1914; a partir de ese año se evidencia en su correspondencia un vivo interés por viajar a los Estados Unidos, en el fondo está el deseo o la necesidad de reunirse con Eloy. Utiliza diferentes pretextos, entre ellos la intención de estudiar diversas cuestiones relacionadas con una modernidad que penetraba a las capas populares y trascendía hacia los problemas sociales que había engendrado: "estudiar los colegios de niños anormales, las cárceles de mujeres, la cinematografía, las industrias femeninas". Cualquier proyecto era válido porque en el fondo latía el deseo de ayudar al hijo que vivía entonces en Staten Island. A pesar de todos sus intentos no logró desplazarse, su situación económica era precaria y no podía hacerlo con recursos propios.

A Eloy y su familia los trajo a Cuba, inicialmente, desde Buenos Aires donde "nos habíamos quedado sin un kilo, como llaman aquí a los centavos". Mientras que éste viajaba a Saint Louis, en Missouri, como director de una fábrica que dependía del Banco Español de la Isla de Cuba, ella los mantuvo:

"a las enormes dificultades en que me desenvolvía para sostener doce personas dentro de mi casa, puedo añadir la falta de comunicación hasta con mi hijo, y al finalizar los once meses, cuando ya mi vida no tenía más que una solución desesperada, pude embarcarlos [...] al entrar en casa y encontrarme sin ellos, tuve valor para dar gracias a Dios porque se habían marchado". ${ }^{14}$

En Estados Unidos Eloy tuvo dos hijos más. Para 1927 había muerto y Eva, con setenta años, se consideró responsable de sus ocho nietos. Ante la adversidad reaccionó con una energía desmesurada para sus años: intentó escenificar sus obras sus obras a través de la Isla, pretendió llevarlas al cine en los Estados Unidos para lo cual solicitó la subvención del Duque de Alba. También manifesta, sobre la base de su furibundo españolismo y de su autosuficiencia, que puede ser una especie de embajadora del Rey en todo el continente; sólo ella sabría hacerlo, sólo ella podría, sólo ella actuaría adecuadamente. Pero detrás de ese accionar sólo está una

14 BPR, "Carta de Eva Canel al marqués de Navas", no tiene fecha, pero una nota dice que fue respondida el 21 de julio de 1924; por el asunto debe haber sido escrita ese propio año. 
pobre mujer desesperada: "la muerte de mi hijo, señor, ha truncado mi vida moral y material [...], ha muerto en tan desgraciadas circunstancias que me fue necesario comenzar de nuevo a ganar la subsistencia, no mía, sino de ocho criaturas". ${ }^{15}$

De nuevo, como en 1889, está sola frente a la adversidad. Ha vivido, ha resistido, ha luchado. Es solo una mujer anciana que aún intenta sostener su familia.

\section{Conocer a Pedro para entender a Eva}

Un análisis psicológico de Eva Canel pudiera demostrarnos que, formada junto a su marido - era una adolescente cuando se casó-, admirándolo profesionalmente, compartiendo con él una vida joven, pletórica de aventuras y desasosiegos, lo convirtió en su modelo de vida. Deseó ser famosa, aplaudida, hablar en público, polemizar, fundar periódicos, escribir novelas y obras de teatro y también, a su forma, participar en la política, aunque, a diferencia de Pedro, estuviese siempre del lado más conservador.

Para tener una noción del paralelismo que la Canel, consciente o inconscientemente desenvolvió, es imprescindible conocer algunos detalles de la vida de Perillán Buxó. Sus avatares se aproximan a los de una novela por entregas, buena parte de estos fueron compartidos con ella y evidentemente condicionaron sus futuras acciones.

Pedro nació en Valladolid el 21 de junio de 1848. Fue el primogénito de un médico izquierdista al que conocían por el "Marat de Castilla la Vieja", que era por más señas, aficionado a escribir poesía satírica. Como también fue militar se trasladaba de un sitio a otro con su familia. Los Perillán vivieron en Madrid, Aragón, Valencia y Andalucía; finalmente se avecindaron en la Corte, donde el padre era estrechamente vigilado por sus devaneos revolucionarios.

Pedro heredó o asumió muchas de las características paternas. A los 13 años escribió su primera comedia titulada Los Negreros. También comenzó a estudiar medicina pero abandonó la carrera en el cuarto año, matriculó entonces en las Facultades de Derecho y de Filosofía y Letras, sin embargo tampoco concluyó estos estudios. Realmente sus intereses lo

15 BPR, "Carta de Eva Canel al marqués de Navas, 27 de enero de 1927". 
llevaban a pasar todo el tiempo en la redacción de los periódicos y en los pasillos del Congreso y del Senado.

A los 18 años estuvo detenido por vez primera. En esa época escribía en El Madrileño, en Los Sucesos, en El Cascabel y en Gil Blas, que eran los periódicos satíricos de mayor importancia. También por entonces compuso, entre otras, sus comedias Un millón y dos Estrellas, Todo por un Simón, La sortija de Pelo, Colón Cortés y Pizarro, Un Secreto entre Mujeres, El amor y el cornetín, Cisco de retama, y La Antesala del Ministro.

Sin abandonar la vida de teatro — entre 1869 y 1873 escribió más de cien obras-, fue articulista de La Discusión y de El Pueblo y formó parte de la redacción de Jeremías. También publicó en El Certamen, La Nación y La Iberia, y fundó algunos periódicos semanales como El Tío Palique y El Domingo.

En enero de 1874 se trasladó a América, debido al golpe de estado ejecutado por el General Pavía. Entró en Uruguay, sin más ropa que la puesta, y pronto empezó a trabajar en El Siglo, pero las convulsiones políticas motivaron que a principios de 1875 tuviera que abandonar ese país clandestinamente. Llegó a Buenos Aires en un vapor, disfrazado de fogonero; allí fundó poco después el semanario satírico El Petróleo. Perseguido nuevamente marchó a Chile donde reanudó su afición teatral: escribió la comedia El Bajá de Melipilla, fundó la Compañía Buxó y contribuyó a formar el Teatro Nacional.

También manifestó otra peculiaridad, su gusto por la exploración de regiones escasamente conocidas, que años más tarde adoptaría la Canel al escribir una serie de artículos sobre el Estrecho de Magallanes. Con Eva se embarcó para Mollendo, cruzaron el lago Titicaca y se presentaron en la ciudad de La Paz, que entonces gobernaba Hilarión Daza. Fue amigo de Sucre y compartió con las pobres "rabonas". ${ }^{16}$ Fundó el primer diario de Bolivia El Ferrocarril $;{ }^{17}$ allí estuvo un año, hasta que la amistad con Daza se fue enfriando, entonces concibió la idea de visitar a los misioneros franciscanos, y a las tribus aborígenes que habitaban más allá de las Yungas, en las fértiles orillas del río Ucayali, y allá se fue con los frailes, vistiendo el

16 Nombre que en Bolivia y Perú se daba a las mujeres que compartían su vida con los soldados, la rabona era la compañera, la hermana, la esposa y hasta la acémila del defensor de la patria, le guisa lo que come, cría a sus hijos, y arregla su rincón en el campamento, transporta sobre los hombros el abultado quipo en que lleva todos los cachivaches, todos los menesteres del ajuar ambulante y los animaluchos domésticos de su corral y las criaturas de pecho. En los combates avanzaban chiateando, es decir, lanzando gritos agudísimos que hacen tililar con el palmoteo de las manos junto a la boca.

17 Hasta ese momento la ciudad solo contaba con periódicos bisemanales. 
hábito, ejerciendo de lego, porque sin aquella indumentaria era seguro que los chunchos no le hubieran permitido entrar en sus tolderías. Estuvo 64 días entre los nativos, estudiando sus costumbres, sus dialectos, su modo de ser, presenciando sus fiestas y simulacros de batallas, regalándoles baratijas de quincallería a cambio de arenas de oro, flechas y pieles de animales.

Marcharon entonces a Lima, donde Perillán publicó el periódico humorístico La Broma, y el diario Las Noticias. En este país prosperó, fue secretario de La Compañía de Obras Públicas y Fomento del Perú, socio director de la Editorial Prince y Buxó, arrendatario de una quinta agrícola en Lazo, propietario y redactor de El Comercio Español y fundador de El Casino Español; nunca antes había tenido tanto dinero, su capital se calculaba en 100.000 duros.

Durante la Guerra del Pacífico estuvo de parte de Perú y Bolivia, fundó hospitales de sangre, organizó legiones sanitarias, renunció a una subvención oficial de 75.000 duros para gastos de sanidad militar, confiando a la caridad y al patriotismo de las damas limeñas las provisiones del campamento. Refería, como el más valioso de sus triunfos, que las mujeres en la capital peruana, desde la más aristocrática a la más humilde, lo habían esperado en la Plaza de la Exposición y desde allí lo hicieron apear del caballo y lo llevaron en andas dando vivas al amigo extranjero que les devolvía sus esposos, sus hijos y sus hermanos recogidos en el campo de batalla.

Tras la derrota, escapó de los chilenos y cruzó los Andes. Después de sesenta días de caminatas y escondrijos llegó al puerto ecuatoriano de Guayaquil, allí se reunió con Eva y con su hijo Eloy. A bordo del Saint Simon arribaron nuestros viajeros a Santander en agosto de 1881; se trasladaron a Madrid en septiembre del mismo año, entonces resurgió en la capital de España La Broma, que llegó a ser el periódico más popular de su genero. Escribió para el teatro Las Macetas, ¡Hatchis!, y Los Matadores y paralelamente daba conferencias en los Casinos y Ateneos. Se dice que era buen orador y excelente polemista.

Pero en la Península tenía causas pendientes, estuvo desterrado en Valdemoro y solo gracias a las gestiones de su mujer con el marqués de Comillas, pudo regresar a Madrid. En esta ciudad estuvo, dirigiendo y redactando el diario La Correspondencia Imparcial, hasta octubre de 1885, cuando un ataque cardíaco lo puso a las puertas de la muerte. Regresó a Barcelona, donde publicó artículos en El Tribuno, La Broma, El Jaleo y El Zurriago, y colaboró en El Siglo, La Vanguardia, La Ilustración Artística y 
El Noticiero Universal. Para el teatro escribió el melodrama El Maldito o Un río de oro, la comedia en un acto N.S.E y O, y la popular revista De Madrid a Barcelona, y estrenó el juguete De Juerga. También publicó un tomo de novelitas y cuentos ligeros titulado Bengalas, que se agotó en dos meses.

Finalmente Perillán decidió "volver a las andadas y a conocer la parte de América que no he vivido: Cuba, Puerto Rico, Méjico y Centro América. Allá voy como peregrino de la idea, sin más caudal que mis obras, ni más compañera que mi pluma, ¿Volveré?”. ${ }^{18}$ Esa sería su última empresa.

La vida de Eva Canel, desde la muerte de su marido, revela un marcado deseo de imitar sus acciones. Escribe para el teatro, publica novelas, redacta en diversos periódicos, utiliza todos los espacios posibles para presentarse en público como conferencista u oradora, incursiona en la Trocha, viaja a la Tierra del Fuego, es Secretaria de la Cruz Roja Española. Trata de trascender en los espacios públicos, para el privado sólo conserva el papel de madre.

\section{¡Oh Martí, Martí! ¡Qué falta nos has hecho a todos!19}

Imposible parece encontrar escrita esta frase en una mujer que fue, sin lugar a dudas, una furibunda integrista, monárquica confesa, apasionada defensora de la permanencia del poder colonial en Cuba.

Valdría entonces la pena construir algunas facetas de la personalidad de Eva, percibir el contexto en que conoció a José Martí, y tener una visión compleja y matizada de las relaciones humanas. La Canel se encuentra con Martí en Nueva York en 1891, cuando aún no había manifestado su incidencia en la conformación de una opinión pública proclive a la permanencia de los vínculos coloniales y pensaba que podía trabajar en la nación norteña.

En la Península se divulgaba un supuesto interés de los Estados Unidos por todo lo español con motivo de las actividades que preparaban para la conmemoración del Cuarto Centenario del Descubrimiento. En Nueva York estaba la escritora Mary Serrano, que había traducido al inglés $211, \mathrm{n}^{\circ} 811$.

18 Carta de Perillán Buxó en Archivo Nacional de Cuba, Fondo Academia de la Historia, Caja

19 Canel: Lo que vi en Cuba..., pág. 173. 
algunas obras de autores españoles y también José Martí, a quien había conocido a través de una relación epistolar con el escritor ecuatoriano Nicolás Augusto González. De ambos diría que "procuraban darme ánimos al verme descorazonada". ${ }^{20}$

Veintitrés años más tarde la Canel confesará de su relación con Martí que "jamás hablamos de política española en general, ni antillana en particular; pero sí mucho de España, de literatura, de razas, de sociología, de hombres y de hechos [...] rehuía la conversación política él y yo, en aquel tiempo, no estaba facultada por la experiencia para abordarla ni rozarla siquiera". ${ }^{21}$

Él, que la llamaba amiga, la despidió al salir para Cuba con una caja de bombones y le dijo: "No me escriba. Yo no le escribiré tampoco [...] porque no escribo a quienes bien quiero. Podría llegar a comprometerles". ${ }^{22}$ Dice Eva que la comparaba con su madre, cuestión poco probable porque entonces ella tenía 34 años y Martí 38.

A pesar de esa "ingenua" aclaración, cabe destacar que Eva vivía en Cuba cuando se produjo la Conferencia Panamericana, cuando se fundó el Partido Revolucionario Cubano, cuando se ocuparon las armas del Plan de Fernandina y también cuando su amigo Pepe, como le llamaba, murió en Dos Ríos. Hasta junio del 95 no funcionó en Cuba la censura de prensa para los asuntos de la guerra, sin embargo no mencionó a Martí en sus escritos de esos años, ni siquiera se refirió a la visión que éste tenía de la política norteamericana, o de su humanismo, o tampoco de su avenencia con los españoles de las capas populares que vivían en la Isla.

Esperó a 1914, cuando la construcción simbólica del paradigma martiano estaba arraigada, entonces publicó las cartas de Nueva York, en que éste firmaba como su amigo, ${ }^{23}$ y escribió para El Cubano Libre un artículo titulado "El Gran Místico (después de rezar en la tumba de Martí)", ${ }^{24}$ en el cual la contradicción política que le había impuesto un "olvido voluntario" se manifiesta subrepticiamente cuando lo mitifica: “Sufría? ¿Gozaba? ¿Dudaba? ¿Creía? [...], nacía la sorpresa de verse frente a un místico reconcentrado en sí mismo", ${ }^{25}$ en tanto que paralelamente reconocía que "Martí tenía de terrenal el profundo conocimiento del pueblo y de los políticos

20 Ibídem, pág. 12.

21 Ibídem, pág. 204.

22 Ibídem, pág. 206.

23 Aparecen publicadas en Ibídem, págs. 207 a 214.

24 Ibídem, págs. 203-207.

25 Ibídem, pág. 204. 
norteamericanos. Su aversión hacia ellos [...] se acentuaba con la frase rápida, precisa, categórica, para presentarlos, retratarlos y definirlos". ${ }^{26}$

Pero de la política colonial de España en Cuba Eva no dice ni una palabra, ha pasado el tiempo y se repite el silencio comprometido y culpable de sus primeros años en la Isla.

\section{Eva escritora, periodista, viajera}

Si la Eva viajera estuvo presente desde que Perillán vivía, e inclusive a él debió su gusto por las aventuras y por conocer nuevos lugares, solo tras enviudar se manifiestan con fuerza sus intentos como periodista y escritora.

La primera oportunidad de vincular sus aficiones aventureras al periodismo, la tuvo cuando fue enviada como cronista de la Cámara de Comercio de La Habana a la Exposición de Chicago y remitía dos trabajos mensuales que se distribuían a decenas de periódicos. Sin embargo, basándonos en sus propias consideraciones, sus momentos cumbres fueron la excursión a la Trocha de Júcaro a Morón en 1898, y su viaje a la Tierra del Fuego en 1905.

La excursión fue una maniobra de Valeriano Weyler para manipular la opinión pública de la Isla y dar la impresión de que la insurrección estaba totalmente controlada. Su nefasta y sanguinaria política descansaba en tres pilares: deportación de los laborantes ${ }^{27}$ y presuntos conspiradores de las ciudades; reconcentración de la población campesina en espacios urbanos, para evitar su ayuda a los insurrectos; y construcción de trochas militares para contener en determinadas zonas al ejército mambí.

En esta última dirección mandó construir una trocha, de Mariel a Majana, para contener las fuerzas de Antonio Maceo en Pinar del Río, y a fortificar aún más la de Júcaro a Morón, levantada durante la Guerra Grande, con la intención de hacer retroceder hacia la zona oriental a los patriotas y aislarlos en ella.

La propaganda en torno a la construcción de estos baluartes militares era importante, pues los cubanos debían conocer detalladamente lo que Weyler estaba haciendo para de esa forma demostrarles y convencerlos de que no tenían posibilidades para resultar vencedores. Así surgió la idea de realizar una "excursión" de periodistas a la ciudad de Cienfuegos, plaza

26 Ibídem.

27 Desde la Guerra de los Diez Años se daba este nombre a todos aquellos que, de una u otra forma, ayudaban a la insurrección. 
fuerte del integrismo, y después, por mar, continuar viaje hacia la Trocha. Todo aparecía como muy espontáneo, pero desde luego no era más que un montaje propagandístico. Los periodistas implicados fueron Nicolás de Gamboa, Antonio Porrúa, Fernández de Castro y Eva Canel. Estos publicaron un álbum con sus impresiones y las anécdotas del viaje, que dedicaron al sanguinario Valeriano Weyler, marqués de Tenerife.

En éste abundan las fotos, en algunas aparece Eva, gorda, peinada con la raya al medio y un ajustado traje de cuadritos blancos y negros - tal vez por eso conocía directamente las necesidades de un buen corset-, junto a ella su primera "dama de compañía", Claudia Touceiro y González — pues una señora no debía viajar sola-. Esta aprovechó su estancia en Cuba mucho mejor que la Canel al casarse, años después, con un rico comerciante.

Pronto la periodista se convirtió en el centro del viaje: "Eva se enamora [...] de todo lo que es estudiar a nuestra España militar, esa fase hermosísima de una patria tan grande, tan heroica y tan adelantada". Su presencia femenina era importante porque aparecía como un símbolo maternal, portador de sentimientos caritativos, siempre dispuesta a estar al lado del soldado enfermo o herido. Otra foto capta su imagen repartiendo pesetas entre los soldados que viajaban en el Purísima Concepción, con rumbo a Júcaro. ${ }^{28}$

En el hospital de Ciego de Ávila, con su brazalete de la Cruz Roja Española, ${ }^{29}$ aparece visitando a los infelices voluntarios enfermos, la propaganda continúa: "Eva quiere a los soldados como si fueran sus hijos, los mima, les habla en su dialecto a los más, les pregunta si tienen padres, si han dejado novia en el puerto, les toca las manos y la frente, de cama en cama recorrió cuatrocientas ochenta y dos". ${ }^{30}$ Aparece como una madre generosa que reparte obsequios, y no es que personalmente no pudiese serlo, sino que a partir de esto se construye deliberadamente una imagen de altruismo, aunque esta generosidad resultaba restringida, desde luego, a los soldados españoles.

En el Álbum también se habla de una figura que no podía ser obviada, Manuel Calvo, jefe en la sombra del fuerte grupo de poder pro-peninsular, ${ }^{31}$

28 Álbum de la Trocha. Breve reseña de una excursión feliz desde Cienfuegos a San Fernando, recorriendo la línea militar, por cuatro periodistas, junio 1897, La Habana, 1897, págs. 8-9.

29 La Cruz Roja Española solo prestaba ayuda a los soldados y voluntarios peninsulares, fue fundada bajo el gobierno del Capitán General Arderius. Eva fue siempre su secretaria general. Bajo la presidencia de Irene Arana de Novo, esposa del gallego José Novo, comenzaron a utilizar el uniforme de rayadillo, por considerar, según Eva, que éste género era práctico y lavable

30 Álbum de la Trocha..., pág. 32.

31 Para más información sobre Calvo, ver Barcia: Elites y grupos... 
aparece como "gran patriarca de los leales [...], encarnación de la patria española en Cuba, amparo del desvalido, benefactor de la humanidad y corazón tan grande como Euskaria, donde vio la luz". ${ }^{32}$

Pero estas imágenes, creadas intencionalmente, no resultaron perdurables; para los voluntarios la guerra significaba enfermedad y muerte, en los campos de batalla se sentían solos y abandonados, sin saber a ciencia cierta qué defendían. Eva Canel, por el contrario, recordaría esta excursión años más tarde, en su correspondencia con el marqués de Navas, ${ }^{33}$ como uno de los momentos más felices de su vida, cuando la llamaban la Señora, la Dama del Morro, y los soldados la adoraban.

Por sus servicios a Cuba, antes del 98, Weyler solicitó para ella el título de marquesa de Rodas y la Gran Cruz del Mérito Militar con distintivo blanco; ya le habían entregado todas las condecoraciones de la Cruz Roja Española y una placa de honor. Tras la muerte de su hijo, la Canel reclamará reiteradamente los méritos prometidos, probablemente porque estos implicaban cierta retribución económica, ${ }^{34}$ y se encontraba en la mayor pobreza.

Resulta una gran paradoja, tal vez la mayor y más inexplicable de su vida, su admiración por Valeriano Weyler y su declarada fascinación por José Martí.

Un carácter muy diferente tuvieron sus relatos sobre la Tierra del Fuego publicados en Kosmos, que le merecieron ser admitida como miembro de la Real Sociedad Geográfica Madrileña. En diversos números aparecen fotos de los habitantes de la región y se relatan su modo de vida y costumbres. En esa época Eva tenía 52 años y aún manifestaba su gusto por la aventura.

Otra de sus vertientes periodísticas fue la satírica. En 1892 comenzó a editar, a sugerencia de algunos compañeros de profesión, el periódico $L a$ Cotorra, ${ }^{35}$ con una línea similar a la que había tenido La Broma. El periódico se anunciaba, en clara alusión al sexo de su directora, como "Organa

32 Álbum de la Trocha..., pág. 37.

33 BPR, "Carta de Eva Canel al marqués de Navas, 8 de julio de 1929".

34 Ibídem.

35 Solo hemos podido localizar un número de este periódico, el correspondiente al 8 de enero de 1893, año II, $n^{\circ}$ 54, que se encuentra en la Sala Cubana de la Biblioteca Nacional José Martí. Tenía su redacción en la calle Ejido $n^{\circ} 2$, Bajos, y el número suelto se vendía a 15 centavos plata. La caricatura central representa la llegada a Cuba y también la partida de Mr. Call. Este es acosado, a su llegada, por los periodistas de El País y La Lucha, de tendencia autonomista, también se le acerca el periódico La Unión Constitucional, baluarte del integrismo, en tanto El Diario de la Marina le presta menos atención. Al salir del país, una mujer, que simboliza a España, le da un puntapié, en tanto El País y La Lucha, se conduelen. 
(sic) política, satírica y libérrima" y el ex ergo recalcaba: "No sabe tirar el sable (la cotorra). No se bate más que a picotazos". Su triple condición de huérfana, viuda y madre de un hijo menor, supuestas desgracias, permitieron a Eva Canel dirigir personalmente su publicación pues no tenía representante legal que la supliera; ${ }^{36}$ tal vez por esto buscó y encontró en la cotorra una representación simbólica femenina que resalta en el ex ergo, y es que, en definitiva, los "picotazos" iban bien con su compleja personalidad. El periódico se caracterizaba por las caricaturas dibujadas por Rosendo Fernández, quien las ofreció gratuitamente hasta tanto pudiesen cubrirse los gastos de edición.

En su vertiente literaria Eva Canel escribió siete novelas y cuatro dramas, entre las que se destacan Trapitos al Sol y La Pola, redactadas en España. Durante su estancia en Nueva York, escribió, a solicitud de Mary Serrano, una novela que tituló Oremus. Quince días encerrada en un saloncillo del hotel le bastaron para culminar su redacción. El tema de esta obra, como el de otras que escribió, era sumamente escabroso para la época, pues trataba sobre el adulterio, una madre infiel y una hija que no sólo le sigue los pasos, sino que llega a ocultar el asesinato del padre para no implicar a la autora de sus días. Más tarde concluyó en Cuba su novela Manolín, que reitera el tema de los hijos naturales y de las relaciones extra-matrimoniales, algunas con carácter incestuoso al producirse entre miembros de una misma familia. La edición fue costeada por el Centro y la Beneficencia asturianos, en tanto otro comarcano, el marqués de Pinar del Río, aportaba el papel.

Su drama La Mulata, fue estrenado en el Teatro Payret, el 10 de noviembre de 1893; en este caso el tema, también candente, era racial. El padre, catalán y blanco, rapta al hijo que ha tenido con una mulata y lo lleva a España, tras múltiples peripecias, ya adulto, el joven reconoce y acepta a su madre. Poco después llevó a las tablas El Indiano. En diferentes ocasiones la Canel manifiesta sus criterios anti-racistas, durante a su viaje a Santiago de Cuba en 1914 visitó diversas asociaciones de negros y mestizos integradas por individuos amantes del progreso, entonces reiterará:

"yo no distingo de colores, tan solo de educaciones, virtudes y culturas [...]. Ya sé que estas ideas mías, expuestas pública y claramente hace ya muchos años [se refiere al debate generado en torno a La Mulata] encuentran resistencias en la mayoría de

36 A pesar de esto la solicitud del periódico fue realizada por Lucio Suárez Solís, quien manifiesta al gobierno la intención de publicar, a partir del 15 de noviembre de 1891, un periódico semanal con caricaturas, que se imprimirá en el establecimiento tipográfico de D. Manuel Romero Rubio. En: Archivo Nacional de Cuba, Fondo Gobierno General, legajo 181, $\mathrm{n}^{\circ} 10075$. 
las gentes, grandes polémicas he sostenido por lo mismo; y es que yo no comprendo el rechazo de un hombre instruido, educado, por una sociedad tan impura, tan defectuosa, como la que rige hoy los destinos del mundo, ni menos la razón del rechazo montada en diferencias pigmentales". ${ }^{37}$

Los polémicos temas abordados por la Canel abren otra interrogante: ¿Cómo una mujer cuya conducta en la vida real se caracterizó por la intransigencia y la inflexibilidad, fue capaz de abordar en la literatura temas escabrosos y darles las soluciones más audaces? La paradoja continúa.

\section{Eva: feminismo y perturbación social}

En 1896 Eva Canel declaraba: "Soy una mujer a la española, rancia, que practico, por necesidades de la vida moderna, el derecho incuestionable de luchar con tesón y firmeza por el bienestar de los seres que tienen derecho a mis sacrificios" ${ }^{\prime 3}$. ¿Quería decir con eso que era una madre dispuesta a ganar el sustento de su hijo? ¿No resulta esta aseveración una expectativa muy limitada para la Eva escritora de novelas portadoras de profundos conflictos sociales y morales? ¿Cómo relacionar este criterio, con una mujer cuya noción del valor político del espectáculo le permitía cabalgar, en las paradas y desfiles, junto al Estado Mayor Español, vestida con su uniforme de la Cruz Roja? ${ }^{39}$

Afirmaba que no pretendía sustraer a las mujeres de la esfera de acción "que le conceden su sexo y sus actitudes", tampoco consideraba necesario que tuviesen títulos universitarios que las alejasen "de su ambiente y de sus deberes". Pero nada de esto tenía que ver con su comportamiento real, puesto que las acciones de su vida poco se relacionaban, al menos desde 1889, con las de una mujer doméstica controlada por el marido, el padre, o el tutor. ¿Podríamos entonces deducir que la Canel expresaba lo que cada público quería escuchar?; esta ruda conclusión permitiría al menos dar una explicación racional a las paradojas que se establecían entre su decir y su actuar.

37 Canel: Lo que vi en Cuba..., pág. 236.

38 Canel, Eva: Discurso pronunciado por Eva Canel en el Casino Español de México, en la noche del 25 de marzo de 1896, La Habana, 1896.

39 Simón Palmer, María del Carmen: "Escritoras españolas en el extranjero", en Jiménez Morales, Isabel y Amparo Quilez Paz (coords.): De otras miradas: reflexiones sobre la mujer de los siglos XVII al XX, Málaga, 1998, pág. 132. 
Claro que no siempre era así, pues desenvolvió contiendas de las que estaba raigalmente convencida, como por ejemplo la relacionada con el divorcio y no porque el debate en torno al mismo fuese una cuestión religiosa, sino porque lo consideraba un problema social que afectaba "la moral de la familia que era la base de la patria". ${ }^{40}$ La polémica en torno a esta cuestión en el Congreso Nacional Argentino, al cual replicaba la Canel, tenía por base atribuir todos los males, incluyendo ese, a la administración colonial española cuyo Código Civil reflejaba el divorcio como una simple posibilidad de separación en condiciones extremas, pero impedía la concertación de un nuevo contrato matrimonial. Eva, españolista hasta la médula, podía abordar en sus novelas el adulterio pero no era capaz de admitir, en la vida real, una separación legal. Reconocía que el matrimonio "no excluía las pasiones" ${ }^{41}$ estas debían ser combatidas con "severidad" ${ }^{42}$ aunque también con "indulgencia" ${ }^{43}$ Era preferible ser tolerante y tener valor para sufrir, dulzura para amar y "fuerza moral para llevar sobre los hombros la carga que nos resulte pesada". ${ }^{44} \mathrm{Tal}$ vez para no tener que practicar esas "virtudes" decidió no arriesgarse en un nuevo matrimonio.

Se preocupaba por los efectos que el divorcio podía tener en las capas populares, pues esto afectaría el sustento de los hijos, no tenía en cuenta, sin embargo, que en $\mathrm{Cuba}^{45}$ las uniones entre los pobres eran por lo general consensuales y la mayor parte de los niños eran hijos naturales y que por esa razón la ley del divorcio también fue muy debatida, por lo cual tuvo a su favor, esencialmente, a las mujeres de las capas altas y medias de la sociedad. Algo similar debe de haber ocurrido en la Argentina de esos años.

Como los planteamientos realizados por la Canel en la Universidad de Córdoba fueron muy criticados por los principales periódicos, trató de justificar su interés sobre la base del cariño que tanto ella como su difunto marido habían tenido por Latinoamérica. También argumentó los deberes adquiridos con el matrimonio sobre la base de su experiencia personal: "recuerdo [...] que el secretario del juzgado estuvo más de media hora leyendo los

40 Canel, Eva: El divorcio ante la familia y la sociedad, Buenos Aires, 1903, pág. 7

41 Ibídem, pág. 18.

42 Ibídem.

43 Ibídem.

44 Ibídem, pág. 20.

45 Criterios similares a los expresados en Buenos Aires fueron divulgados por la Canel en una conferencia pronunciada en el Centro Asturiano, el 8 de octubre de 1914, inclusive utiliza los mismos ejemplos sobre su matrimonio y sobre los divorcios de la actriz norteamericana Lilliam Russel. Ver: Canel, Eva: El divorcio ante la moral social, La Habana, 1916. 
deberes que imponía la ley a cada uno de los contrayentes, de cuya media hora, solo cinco minutos corresponderían a los deberes de los maridos". ${ }^{46}$

Eva siente placer en reiterar continuamente su posición antifeminista e insiste en que para modificar la situación de la mujer en la sociedad había que comenzar por modificar los sistemas escolares, pues la educación de éstas distaba mucho de asimilar y seguir las pautas modernas. ${ }^{47}$

Celebraba, sin embargo el trabajo profesional de las mujeres, se refería por ejemplo, a las linotipistas cubanas como "dominadoras muy gallardas" de la caja, aunque también confesaba que jamás había creído que esa profesión llegase a tener raigambre femenina..$^{48}$

Protestaba por la desatención social hacia a la mujer que, decía, se encontraba en Cuba muy descuidada, puesto que aunque los españoles habían logrado edificar excelentes quintas de salud, con un sistema de atención poco común para la época, no lo hacían extensivo a sus compañeras, que no hallaban refugio a través del mutualismo, limitándose la atención a aquellas que, por tener una posición acomodada podían pagar sus estadías. ${ }^{49}$

También se refería a que La Habana estaba, a principios del siglo XX, plagada de sirvientas españolas, sin protección ante la marginalidad, ni sistemas educacionales de ningún tipo, acusando a sus propios compatriotas de que muchas de estas cayesen en el abismo por su indulgencia y culpa.

Pero nada de esto se concretaba en una acción social desenvuelta a partir de las mujeres; para la Canel el feminismo perturba, conmueve, trastorna las bases de la sociedad y rompe con su criterio de una familia conceptualmente estable, ese equilibrio debía sostenerse a cualquier precio, aunque fuese pagado por las propias mujeres. He ahí su desacuerdo, con esa corriente, aún cuando, en el plano individual estuviese siempre dispuesta a quebrantar normas y a asumir las consecuencias.

\section{Eva amiga y enemiga. La razón de lo implacable}

Hipercrítica con unos y bondadosa con otros; entre estos extremos se manifestaron muchas de las valoraciones realizadas por Eva Canel a lo largo de su vida. Resentimiento, envidia, rencor, animosidad, resquemor,

46 Canel: El divorcio ante la familia..., pág. 21

47 Canel, Eva: La educación y la ilustración de la mujer. El feminismo como perturbación social, Buenos Aires, 1903.

48 Canel: Lo que vi en Cuba..., pág. 1.

49 Ibídem, pág. 80. 
estos sentimientos debieron estar presentes en algunos de sus juicios, pues Eva no perdonaba discrepancias de ningún tipo, su intransigencia resultaba medular y también, por consiguiente, se manifestaba como inflexible e incapaz de admitir criterios y posiciones divergentes a los suyos.

Ella, paradigma de periodista, no era capaz de aceptar, desapasionadamente, el éxito de otros. Cuando viaja a Cuba Manuel Aznar dice con sorna "aquí nos cayó un fenómeno periodístico, oratorio, petroniano y algo más que se me queda en el tintero [...]. Después de muchos paseos y muchos banquetes en los casinos de moda, muchos discursos en las sociedades españolas, se nos apareció el señor Aznar aceptando la dirección técnica de El País" ${ }^{50}$ y sumamente molesta porque éste había acudido a un acto izquierdista, añade que con motivo de "la muerte de Lenine [sic] se le ocurrió al alcalde de Regla [...] plantar un pino [...] en honor del ruso hirsuto arrastrando consigo todos los bolsibikes [ $\mathrm{sic}]$ hojalateros que sumaban dos o tres mil". ${ }^{51}$

Eva incursiona en todos los campos, incluyendo el económico, y en todos piensa puede sentar cátedra. De Ruano de la Sota, ex Ministro de Hacienda español, dirá: "Pobre señor, si no posee otros más que los problemas estudiados ahora, le vamos a dar un suspenso morrocotudo precisamente en lo que cree dominar". ${ }^{2}$

Las vanguardias le daban escozor: ya anciana, replicaba porque la Academia nombraba como miembros correspondientes a los "vanguardistas". Utilizando el rumor sobre la vida privada, la emprendió, ignorando su ya destacada presencia en la cultura cubana, contra un joven y prestigioso intelectual llamado Jorge Mañach, del que proyectó una mixtificada imagen pública cuando solo se refiere a él como "hijo de un abogado gallego, muerto casi trágicamente en una junta de socios del Centro Gallego y casado después con la hija del culpable de la muerte de su padre". ${ }^{53}$ De similar forma ataca y desvaloriza a prestigiosas figuras como Miguel de Unamuno o Rubén Darío, al cual critica, improcedentemente, cuando se hablaba de hacerle un monumento.

De forma similar se comporta con su compatriota Concha Espina, quien de imagen entrañable, se convierte en una figura enjuiciada en su tránsito del anonimato a la fama.

50 BPR. "Carta de Eva Canel al marqués de Navas", no tiene fecha, pero una nota dice que fue respondida el 21 de julio de 1924.

51 Ibídem.

52 Ibídem.

53 BPR, "Carta de Eva Canel al marqués de Navas, 4 de mayo de 1927". 
Concha comenzó a publicar en Kosmos, donde la Canel le abrió un espacio que supo aprovechar y que, indudablemente, agradeció, cuestión que se evidencia cuando años más tarde le dedica unos versos en los cuales explica su iniciación en las letras:

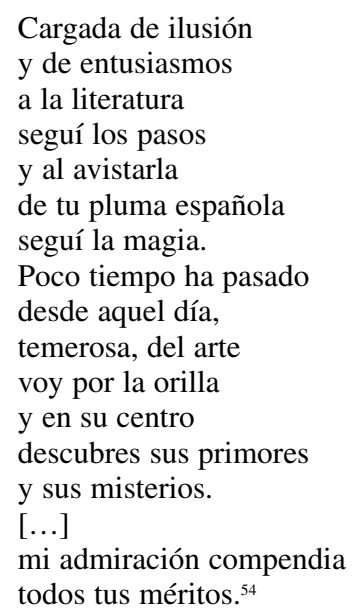

Muy halagada debió sentirse Eva por un reconocimiento que la presentaba como una legadora de favores que iba por el mundo "derrochando ingenio", por lo cual, desde luego, no dudó en divulgar los versos de referencia en Kosmos. Sin embargo, cuando Concha, en una entrevista, hizo referencia a que sus primeros y pequeños sueldos los había ganado en esa revista, Eva montó en cólera comentando que, cuando en España se pagaba 10 pesetas por un artículo, ella le pagaba a la Espina 25, y se refería a que durante su enfermedad del año 1908, cuando ni siquiera se le permitía leer la correspondencia, ésta le había escrito colérica porque no se le había liquidado un trabajo, entonces su primo Francisco Canel, se ocupó del asunto. Todo terminó con una amistosa misiva de Concha.

La Canel resultaba implacable en todo lo que se relacionaba con su autoestima, y nunca perdonó a su compatriota. Refería que ésta no sabía hablar en público y que, cuando en el año 1927 había visitado La Habana, no había sido capaz siquiera de leer su propia conferencia, por lo cual ella

54 Estos versos, que fueron publicados en la revista Kosmos, aparecen mecanografiados y fechados en 1906, entre la correspondencia de Eva Canel al marqués de Navas, conservada en la Biblioteca del Palacio Real de Madrid. 
debió sustituirla, interpretando como una incapacidad lo que posiblemente fue una deferencia. En su correspondencia con Navas criticaba la forma de redactar de la Espina y expresaba: "no es tan buena" y maneja inadecuadamente el castellano, pues utiliza la frase "hablarles a ellos", en lugar de "hablar a ellos", que es la forma correcta. En su correspondencia con Navas, relata su supuesta polémica con Nicolás Rivero, director del Diario de la Marina, periódico que no dejó de leer durante su estancia en Buenos Aires, porque éste no publicó un artículo que le había pedido; el fondo de la cuestión era muy simple, éste le había solicitado una crónica sobre Concha Espina y ella había escrito un trabajo cuyo protagonista era la revista Kosmos. Más tarde consiguió editarlo en el periódico El Diario Español, del gallego Adelardo Novo, la anécdota muestra el evidente protagonismo de la Canel, que de una u otra forma no se conformaba con ocupar un segundo plano.

Sin embargo, se refería con respeto y afecto a Mercedes Matamoros, de quien imprimió un poemario, a Celia Delmonte de Delmonte, a Luisa Pérez de Zambrana y a Domitilia García de Coronado, con quienes había compartido en Cuba. A Luisa la consideraba "la dulce poetisa, la mujer mártir, aquella a quien no dije adiós en el 98 "55 y que, sin embargo, le había escrito un poema a su regreso a la Isla; a Domitila la caracterizaba como "galana escritora y culta pedagoga" ${ }^{56}$ Pero ninguna de éstas habían sido sus antagonistas.

\section{Su españolismo: ¿añoranza o necesidad de reconocimiento?}

Eva Canel no ha sido reconocida en la Península como una mujer de las letras españolas; situada entre dos mundos no fue juzgada en su época como tal, en tanto tampoco puede considerársele como americana, pues continuamente reivindicaba su peninsularidad. Carmen Burgos, por ejemplo, se refería a ella como "la gran escritora argentina", ${ }^{57}$ pues fue muy conocida a través de la revista Kosmos, editada en ese país.

Extranjera para unos y ausente para otros, nadie la reclamaba con la fuerza que ella deseaba; esta realidad debió herir su ego y su manifiesta

55 Canel: Lo que vi en Cuba..., pág. 26.

56 Ibídem, pág. 238. $4, n^{\circ} 6$.

57 Burgos, Carmen: "Conferencia Femenina", Revista Fémina, La Habana, junio de 1912, año 
susceptibilidad, sin embargo Eva siempre se sintió y también se manifestó como española a ultranza, al punto de representar en Cuba, durante su primera estancia, de 1891 a 1898, a los elementos políticamente más reaccionarios. Reflejaba su intransigencia, durante la Guerra de Independencia , no solo a través de sus escritos, sino de sus actitudes: vestía el uniforme de rayadillo de la Cruz Roja Española, que ella misma sugirió implantar, aparecía en los actos oficiales no como periodista sino en función de ese cargo y manifestaba su apoyo incondicional a la política oficial, y a la acción genocida de Valeriano Weyler. Cuesta trabajo pensar que una mujer que viviese en Cuba, con la experiencia de la Canel, pudiese respaldar la reconcentración que aniquiló a buena parte de la población civil del occidente del país, sobre todo a niños y mujeres.

Mientras que Eulalia de Borbón, hija de Isabel II, en viaje oficial a la Isla, llegaba a decir en 1893 que a los cubanos "les sobraba razón en sus deseos de libertarse", ${ }^{58}$ ya que España siempre había desoído las peticiones de los insulares, la Canel, viuda de un liberal, entendía su españolismo como la adhesión a las posiciones más reaccionarias.

Años más tarde reivindicará, bajo el concepto de fidelidad, esas acciones y considerará que nadie, fuese cónsul, diplomático o embajador, podía representar con mayor devoción y lealtad que ella, la política española en cualquier parte del mundo; se consideraba una especie de emisaria del Rey. ${ }^{59}$ Llegó a expresar, inclusive, que sería preferible para el gobierno español relacionarse con los Estados Unidos que con los países latinoamericanos, ya que estos habían renegado de su metrópoli. Desde luego este criterio se enmarca en sus deseos de establecerse en la nación donde vivía su hijo.

Por esa razón mucho debieron agradarle los versos de Concha Espina:

$$
\begin{aligned}
& \text { Y si de ti me cuentan } \\
& \text { divinas cosas } \\
& \text { la mejor es que sabes } \\
& \text { ser española. }
\end{aligned}
$$

Durante su segunda estancia en Cuba, que se prolongó hasta el fin de sus días, criticaba a los inmigrantes peninsulares, pues consideraba que circunscribían la patria al Centro Regional y a la Casa de Salud que habían construido en la emigración, y estimaba que de esta forma competían entre sí, en lugar de unir sus esfuerzos y considerarse españoles antes que todo.

58 Borbón, Eulalia de: Memorias, Madrid, 1991, pág. 178.

59 BPR, "Carta de Eva Canel al marqués de Navas, 27 de enero de 1927". 
En esos momentos gran parte de los establecimientos regionales eran más poderosos que el Casino Español, los criterios de la Canel apoyaban las intenciones controladoras de los miembros del Casino pero no tenían peso alguno en las decisiones que pudieran tomarse al respecto.

Muchas posiciones de la Canel fueron interesadas y también parciales, en sus cartas a Navas, que era funcionario de la Monarquía, hacía comentarios que podían incidir en el destino de algunos funcionarios. Del presidente del Centro Gallego en la Isla diría que era "un abogado renegado, toda vez que tiene carta de ciudadanía cubana", también difama al ministro de la Legación Española en Cuba Alfredo Mariátegui, que aspiraba a ser nombrado Embajador, del cónsul expresará "que no ha sido nunca modelo de moralidad", y en su correspondencia privada se referirá a los escándalos que daba y a sus relaciones con las coristas. ${ }^{60}$

No se trata desde luego, de valorar la equidad de las observaciones realizadas por Eva, sino de la forma utilizada y de las conclusiones a que llega al expresar que a Cuba, en 1924, debía venir nada menos que "un militar de los que calzan todavía borceguíes y se ponen medias de lana en el invierno, que no haya nacido en Cuba [...] que venga a oír no a los aduladores de siempre, si no a los que saben hablar". ${ }^{61}$

\section{Nueva visión de Cuba, el regreso}

¿Por qué razón regresó Eva Canel a Cuba? Había salido en 1898 en un momento crucial: el crucero Maine había explotado en la bahía habanera, habían perecido cerca de trescientos marinos norteamericanos y la situación era manipulada políticamente, tanto por el gobierno norteamericano como por los emigrados cubanos, para precipitar el fin del conflicto. En sus relatos ella, protagonista siempre, potencia su protagonismo y dice que, junto al periodista Paco de Oro, se la acusaba por el estallido del barco, y que por esa razón había sido evacuada a México. Esta interpretación, desde luego, resulta disparatada, aunque es evidente que el Capitán General Ramón Blanco Erenas, que había sustituido a Valeriano Weyler, deseaba

60 Hace referencias a que la policía entró en "un bailongo asqueroso" y encontró "al Ministro de España que era el más vestido de todos porque estaba en calzoncillos y camiseta". Añade que "se le podía ver por la calle acompañando a una mulatona y llevándola al teatro[...]. En el barrio de Jesús María es muy popular a causa de la canela en caña" [subrayado en el original]. BPR, "Carta de Eva Canel al marqués de Navas, 1 de julio de 1923".

61 Ibídem. 
evitar todas las confrontaciones posibles y tanto Eva como su colega eran sumamente contestatarios.

Sus explicaciones sobre el retorno son diversas; en el libro publicado en Cuba en 1916 expresa que el médico, durante una estadía en Panamá, le dijo que sufría "una sobreexcitación cerebral", que el insomnio la extenuaba, por lo cual requería reposo y silencio; no obstante ella consideraba —influenciada por Felicia, su segunda dama de compañía-, que lo que necesitaba realmente era volver atrás, ver a su hijo, a sus nietos, a sus compañeros más queridos. Entonces le escribió a su amigo y compadre Antonio Díaz Blanco, quien le propuso viajar a Cuba para descansar, en lugar de internarse en un solitario hospital.

¿Buscaba eso Eva cuando se decidió a escribir? ¿Cuál era el motivo de su depresión? Ella no tenía bienes de fortuna, vivía de su trabajo periodístico y editorial, ingresar en un hospital significaba un gasto considerable, en su correspondencia también se refleja la insolvencia del hijo. Frecuentemente conversaba con un amigo asturiano sobre España, y sobre los acontecimientos políticos y sociales del momento, entre los que se destacaba la apertura del Canal de Panamá. Relata que éste le había puesto una guajira en el fonógrafo y ella había roto a llorar "como si hubiese sido la praviana". ${ }^{62}$ En otra referencia dirá "Yo no he podido oír una guajira, después que salí de Cuba en 1898, sin llorar amargamente";63 no era Eva, sin embargo, una mujer con la sensibilidad a flor de piel. El motivo de su crisis se hace evidente cuando expresa: "me giraba por cable mi buen compadre trescientos dólares para ayudar a mis gastos". ${ }^{64}$ En Cuba pensaba encontrar todos los remedios para sus males.

La correspondencia con Navas refleja que había salido de Buenos Aires cuando se decía que los norteamericanos harían pasar un buque por el Canal de Panamá con motivo del Cuarto Centenario del Descubrimiento del Pacífico, en septiembre de 1913, pero todo resultó ser falso; también expresa que la Primera Guerra Mundial había trastornado todos sus planes y la había obligado "contra todo deseo" a radicarse en Cuba, ${ }^{65}$ a la cual había regresado tras dieciséis años de ausencia.

Pero, a pesar de todo, reconocía que la capital que dejó, poco tenía que ver la ciudad que la recibía. Recalcaba, desde luego, que este progreso

62 Canel: Lo que vi en Cuba..., pág. 3.

63 Ibídem, pág. 230.

64 Ibídem, pág. 4.

65 BPR, "Carta de Eva Canel al marqués de Navas, 27 de enero de 1927". 
no se debía a la independencia sino al "impulso del progreso universal en los últimos tres lustros" —es decir, retrotraía el inicio del esplendor a la etapa colonial- y remarcaba aún más: "los españoles con sus grandiosos edificios sociales, los propietarios fabricando casas numerosas, han hecho de la capital de la isla de Cuba una hermosa ciudad y todavía promete mucho, porque va en crescendo" $[$ sic $] .^{66}$

Pero también reconoce que al entrar por el puerto no había reconocido a la ciudad, que no respondía a sus recuerdos: "Aquella boca por donde yo había entrado cinco veces, en el transcurso de ocho años, me parecía desfigurada [...] ¡El Vedado! ¡Es el Vedado que ha crecido, que se ha transfigurado! [...] Aquella Habana que tenía ante mi vista ya no era la de mis amores, la mía se había esfumado, se había muerto [...], en su lugar quedaba una hija acaso parecida [...] pero no era la mía". ${ }^{67}$ Las quintas de Marianao, tristes y abandonadas a su salida del país, se le mostraban con un "atractivo seductor", había tiendas bien surtidas y vías urbanizadas. Eva avizoraba una perspectiva diferente para Cuba: "De este suelo y de este clima se puede hacer la estación invernal de los adinerados y de los necesitados de América y de Europa". ${ }^{68}$

Como antaño, la Canel recorre la Isla, es entrevistada y entrevista, publica en periódicos importantes, se le invita a dar conferencias en los centros regionales, especialmente en el asturiano, se reúne con viejas amistades, viaja a Puerto Rico, recorre esa otra isla donde comprueba, tanto la penetración de la cultura norteamericana como la resistencia de las raíces españolas, y regresa nuevamente.

A finales de los años veinte podrá decir que no pensaba quedarse, que la guerra la retiene en Cuba, que había deseado regresar a Argentina e ir a España, pero la realidad era que añoraba reunirse con su hijo y que el viaje a los Estados Unidos, que tanto ambicionaba, no se le proporcionó, porque ¿de qué iba a vivir allá, sin amistades y sin conocer el idioma? Eloy no podía mantenerla y Primo de Rivera no escuchaba sus ruegos sobre una dispensa diplomática, que aún cuando no estuviese acompañada de los honorarios del cargo, le brindase cobertura para realizar investigaciones que pudieran traducirse, al igual que había hecho durante su estancia en la Exposición de Chicago, en artículos que recibirían diversos periódicos.

66 Canel: Lo que vi en Cuba..., pág. 134

67 Ibídem, pág. 6

68 Ibídem, pág. 34. 
A pesar de sus posiciones durante la etapa colonial, Eva fue acogida en Cuba cálidamente. Pocos se acordaban de sus artículos a favor de Weyler. Por otra parte la inmigración española se había incrementado rápidamente al impulso del crecimiento económico de la Isla. Hasta los años treinta buena parte de la riqueza de Cuba estuvo en manos peninsulares y un número apreciable de éstos se desempeñaban en el pequeño comercio y en la esfera de los servicios de las ciudades más importantes. Como esta inmigración fue mayoritariamente masculina, se habían constituido muchos hogares de padre gallego, asturiano, o canario y madre cubana. Tampoco la concepción martiana sobre la guerra había excluido la participación de los españoles junto a los cubanos, el conflicto se libraba contra la administración colonial, no contra los trabajadores peninsulares que vivían en la Isla. Esos factores incidieron en una asimilación natural de esa presencia en la sociedad cubana. Todo ello se reflejó también en la aceptación a Eva Canel.

\section{Pobreza, tristeza y solidaridad. Sus últimos años en la Isla}

En 1927 murió su único hijo. La Canel, anciana y sin recursos materiales, intentó reproducir sus acciones de otro tiempo para conseguir dinero, pero tenía ya setenta años, afirma que había tenido éxito en La Habana, pero recorrer la Isla reponiendo sus obras teatrales no debía resultarle fácil. No obstante, su situación económica era precaria desde mucho antes, en 1924 el Diario de la Marina ${ }^{69}$ propone comprarle una casa, a ese efecto se crea un comité presidido por José A. Presno y del cual formaba parte Manuel Otaduy, representante en Cuba de la Trasatlántica Española.

En 1928 José Aixalá publica un trabajo sobre la Canel en su columna "Gente de Casa", donde la consideraba la primera mujer conferencista de América Latina. En ese momento Eva, por el relegamiento a las demandas que había realizado ante el gobierno español, afirmaba que éste no la había ayudado jamás.

Para 1929 vivía en un edificio conocido como Palacio Díaz Blanco, ubicado en las calles de Belascoaín y Clavel, propiedad de la familia de su compadre y benefactor Antonio Díaz Blanco, que se lo había facilitado. Considera que su apartamento era modesto, que en nada se parecía a su col.1.

69 "Homenaje a Eva Canel”, Diario de la Marina, La Habana, 28 de mayo de 1924, pág.4, 
casa quinta de Buenos Aires y se quejaba de que el ruido de la calle, de los niños, del transporte, la imposibilitaban de trabajar. Es evidente que vivía sola, y que los nietos, por los que tanto se había preocupado, seguían en los Estados Unidos con la madre.

Eva Canel falleció en La Habana, ciudad que había amado entrañablemente, el 2 de mayo de 1932. Tuvo una vida intensa y llena de contradicciones, luchó contra prejuicios y fue portadora de otros, era prepotente y autosuficiente y debió vivir sus últimos años gracias a la ayuda de sus amigos en la Isla, pero probablemente aún en esos momentos mantenía los rasgos que habían caracterizado su recia y contradictoria personalidad:

"Yo soy la única que puede hablar, la única que no ha tenido subvenciones, porque jamás las ha pedido [...], que no ha gozado de sueldos del gobierno de España [...], que no ha pedido nada ni ha tenido nada [...], que ha escrito voluminosos libros en honra de mi patria y de los españoles [...] y los ha regalado [...]. Algunos españoles residentes en el Nuevo Mundo me han ayudado particularmente a trabajar, no a holgar, ni a divertirme, ni a comprar tierras, ni a hacer casas [...], sin otro afán ni otro objetivo que el de estudiar, unificar, hacer justicia, defender a España contra insidias, injurias, y calumnias". ${ }^{70}$

Pero todo eso, como suele suceder, fue solo una parte de su verdad.

70 Canel: Lo que vi en Cuba..., págs. 377-78. 